NOTE

\title{
Solar UV radiation does not inactivate marine birnavirus in coastal seawater
}

\author{
Shin-Ichi Kitamuraa, 2,*, Shin-Ichiro Kamata ${ }^{1}$, Shin-ichi Nakano ${ }^{1}$, Satoru Suzuki ${ }^{1}$ \\ ${ }^{1}$ Center for Marine Environmental Studies (CMES), Ehime University, Matsuyama 790-8577, Japan \\ ${ }^{2}$ Present address: Department of Aqualife Medicine, Yosu National University, San 96-1 Dunduk-dong Yeosu, \\ Jeollanam-do 550-749, Korea
}

\begin{abstract}
We examined the inactivation kinetics of marine birnavirus (MABV) in a coastal sea, in seawater samples collected from $50 \mathrm{~cm}$ depth. MABV was added to both natural and autoclaved seawater at a concentration of $6 \times 10^{6.43} \operatorname{TCID}_{50}\left(50 \%\right.$ tissue culture infectious dose) $\mathrm{ml}^{-1}$, put in dialysis tubes and incubated at the original depth. The inactivation of MABV by solar UV radiation was examined using light and dark tubes. The infectivity titer of MABV was measured by the TCID 50 method using CHSE-214 cells. Virus infectivity in natural seawater decreased quickly and was below the detection limit by $270 \mathrm{~min}$ in both light and dark conditions; however, virus infectivity was maintained in the autoclaved seawater until $420 \mathrm{~min}$. These results suggest that the loss of virus infectivity is not caused by sunlight UV radiation.
\end{abstract}

KEY WORDS: Ultraviolet · Birnavirus · Seawater · Infectivity · Inactivation

Resale or republication not permitted without written consent of the publisher

\section{INTRODUCTION}

Marine birnavirus (MABV), a member of the Birnaviridae, is an icosahedral unenveloped virus with a genome consisting of 2 segments of double-stranded RNA (Dobos et al. 1979). MABV was first isolated from diseased yellowtail Seriola quiqueradiata in Japan in 1985 (Sorimachi \& Hara 1985). Similar birnaviruses have been isolated from shellfish and other cultured and wild fish from around the world (Sohn et al. 1995, Cutrin et al. 2000, Isshiki et al. 2001). Many of the birnavirus isolates were genetically similar (Kitamura et al. 2000), suggesting that all isolates belong to the MABV group. MABVs have a broad host range in various marine organisms (Cutrin et al. 2000, Isshiki et al. 2001).

The transmission mode of MABVs has not been fully defined. MABVs have previously been detected by PCR from coastal and open seawater (Kitamura \& Suzuki 2000, Suzuki et al. 2001), which suggests that MABV can be reserved in seawater as a cell-free form. In addition, yellowtail ascites virus (YAV) and viral deformity virus (VDV), which belong to the MABV group, could infect the host organism by bath challenge (Maeno \& Nakajima 1997), suggesting that MABVs horizontally infect via seawater. Thus, it is thought that MABVs released from affected fish go on to infect healthy fish. However, we could not isolate MABV from seawater samples (Kitamura \& Suzuki 2000, Suzuki et al. 2001). In order to clarify why it was not possible to isolate MABV from seawater, the inactivation process of MABV should be understood. To investigate the infection route of MABV via seawater, it is also important to know the time needed for its inactivation.

It has been reported that virus infectivity is reduced by exposure to solar ultraviolet (UV) radiation (Suttle \& Chen 1992, Noble \& Fuhrman 1997), high temperature (Chung \& Sobsey 1993) and biological factors in aquatic environments (Yoshimizu et al. 1986a, Kamei et al. 1987). The goal of the present study was to exam- 
ine the inactivation kinetics and discuss whether sunlight can inactivate MABV in coastal seawater in summer.

\section{MATERIALS AND METHODS}

The chinook salmon embryo cell line (CHSE-214) was used for MABV propagation and assay of virus infectivity. Cells were grown at $20^{\circ} \mathrm{C}$ in Eagle's minimum essential medium (MEM, Nissui), which contained $10 \%$ fetal bovine serum (FBS). MABV Strain JPO-97 isolated from the Japanese pearl oyster Pinctada fucata (Kitamura et al. 2000) was used in this study. The virus was inoculated to monolayer cells of CHSE-214 in $75 \mathrm{~cm}^{2}$ flasks (Corning). When the cytopathic effect (CPE) reached $100 \%$ of the monolayer, the culture fluid was harvested. Cells were freezethawed twice to obtain the cell-associated viruses. The culture fluid was centrifuged at $2800 \times g$ at $4^{\circ} \mathrm{C}$ for $20 \mathrm{~min}$ to remove cell debris, and supernatant was used as a virus sample. The infectivity titer was measured by the $50 \%$ tissue culture infectious dose $\left(\mathrm{TCID}_{50}\right)$, calculated by Reed \& Muench (1938) using a 96-well tissue culture plate (Corning).

UV intensity was measured using a PUV-500 (Biospherical Instruments) on 22 and 23 August 2001. The weather on each day was clear, and UV transmission was calculated using the following formula:

$$
\% \text { transmittance }=\left(I / I_{0}\right) \times 100
$$

where $I_{0}=$ intensity of incident monochromatic light at the surface and $I=$ final intensity of transmitted radiation after passing through the seawater.

The present study was conducted in Uchiumi Bay, west coast of Ehime Prefecture, Shikoku Island, Japan, on 25 August 2001. Seawater was collected from $50 \mathrm{~cm}$ depth using a Niskin sampler, and a portion of the seawater sample was autoclaved. A total of $50 \mathrm{ml}$ of natural, autoclaved seawater was poured into sterilized dialysis tubes (Spectrum; MWCO: 3500, molecular mass cut-off of $3500 \mathrm{Da}$ ), and $3 \mathrm{ml}$ of the virus solution was added to each tube at a concentration of $10^{8.43} \mathrm{TCID}_{50} \mathrm{ml}^{-1}$. To prevent breakage, each tube thus prepared was placed in a

Table 1. UV transmission rate at $50 \mathrm{~cm}$ depth

\begin{tabular}{|cc|}
\hline Wavelength $(\mathrm{nm})$ & $\begin{array}{c}\text { \% transmission } \\
\text { relative to surface }\end{array}$ \\
\hline 308 & 74.97 \\
320 & 73.58 \\
340 & 78.21 \\
380 & 82.33 \\
PAR & 82.23 \\
\hline
\end{tabular}

transparent polycarbonate bottle with many holes in it to allow transmittance of UV. In order to know effect of UV radiation, these samples were divided into 2 groups: one exposed to sunlight, the other covered with black cloth to block UV radiation. Thus, we had 4 treatments: natural, light; natural, dark; autoclave, light; autoclave, dark. Each treatment group was performed in triplicate. These treatments were incubated at $50 \mathrm{~cm}$ depth. A subsample was taken from each tube at 20 or 50 min intervals, immediately frozen in liquid nitrogen and then stored at $-80^{\circ} \mathrm{C}$ until use. Before measuring the infectivity, each subsample was filtered through a $0.45 \mu \mathrm{m}$ pore filter (Millipore).

\section{RESULTS AND DISCUSSION}

Water temperature during the experiment ranged between 27.2 and $28.2^{\circ} \mathrm{C}$ at $50 \mathrm{~cm}$ depth. UV transmission at $50 \mathrm{~cm}$ depth was higher than $70 \%$ of the intensity at the surface (Table 1).

The infectivity titer of MABV declined over time in all treatments (Fig. 1). The mean initial infectivity titer was $10^{3.80} \mathrm{TCID}_{50} \mathrm{ml}^{-1}$, even though the original virus solution had a titer of $6 \times 10^{6.43} \mathrm{TCID}_{50} \mathrm{ml}^{-1}$, suggesting non-specific adsorption of the virus to the tube. Virus infectivity in the natural seawater markedly declined after 120 min incubation in both light and dark treatments. The infectivity titers declined below the detection limit $\left(10^{2} \mathrm{TCID}_{50} \mathrm{ml}^{-1}\right)$ after $270 \mathrm{~min}$. By contrast, in the autoclaved seawater virus infectivity was maintained even after $420 \mathrm{~min}$.

Until now, it has been reported that viruses, especially phages, can be inactivated by solar UV radiation in environmental seawater (Suttle \& Chen 1992, Noble \& Fuhrman 1997). The loss of the MABV titer was similar in both the light and dark treatments, although our experiment showed that more than $70 \%$ of the UV radiation was detected at $50 \mathrm{~cm}$ depth. This result suggests that MABV was resistant to solar UV radiation. One type of birnavirus, infectious pancreatic necrosis virus (IPNV), has been reported to be inactivated at 1.0 to $1.5 \times 10^{5} \mu \mathrm{W}$ $\mathrm{s}^{-1} \mathrm{~cm}^{-2}$ (Yoshimizu et al. 1986b). Øya \& Rimstad (2001) reported that IPNV is more resistant to UV radiation than both infectious salmon anaemia virus and viral haemorrhagic septicaemia virus. Liltved et al. (1995) also reported that IPNV was more resistant to UV irradiation (1.99 to $1.25 \times 10^{5} \mu \mathrm{W} \mathrm{s}^{-1} \mathrm{~cm}^{-2}$ was needed for $99.9 \%$ inactivation) than Aeromonas salmonicida, Vibrio anguillarum and Yersinia ruckeri. Together, these reports suggest that birnavirus is resistant to UV radiation, even under laboratory conditions. Our data indicate that solar UV radiation at $50 \mathrm{~cm}$ depth was not strong enough to inactivate MABV. Resistance of birnaviruses against UV radiation may be due to the small size of the virion. 

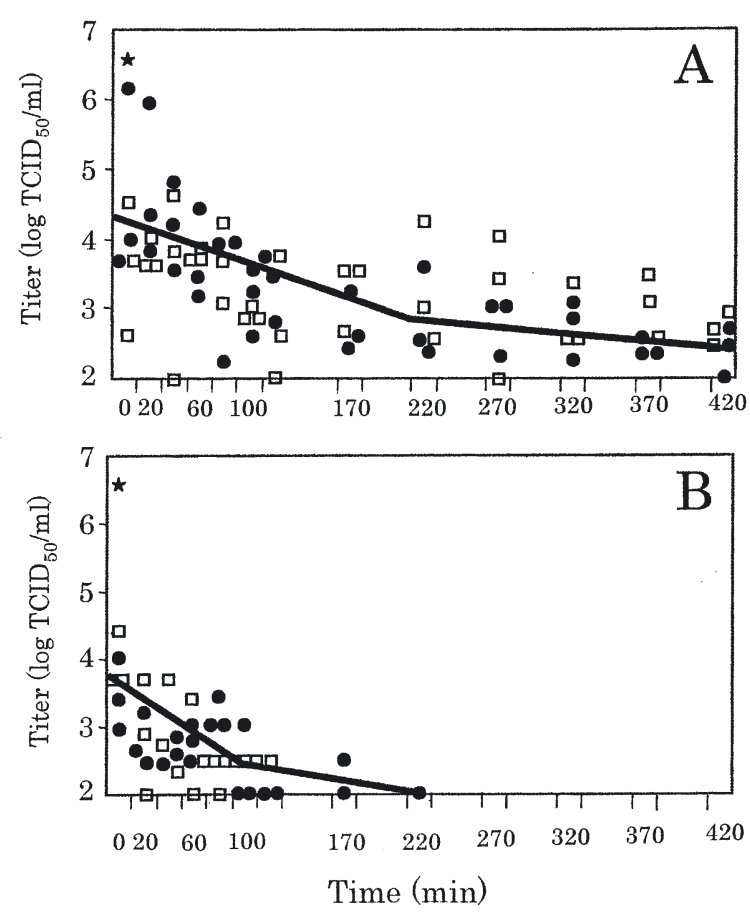

Fig. 1. Infectivity titer of marine birnavirus (MABV) suspended in (A) autoclaved seawater and (B) natural seawater. $(\bullet)$ Dark condition; (ㅁ) light condition; $(\star)$ original virus titer. Detection limit of the infectivity titer was $10^{2} \mathrm{TCID}_{50} \mathrm{ml}^{-1}$

MABV is stable against heating at $56^{\circ} \mathrm{C}$ for $30 \mathrm{~min}$ (Sorimachi \& Hara 1985). Mortensen et al. (1998) reported that IPNV isolated from the scallop Pecten maximus was stable at $30^{\circ} \mathrm{C}$ for $10 \mathrm{~d}$ under laboratory conditions. These findings suggest that birnaviruses are stable at high temperatures. Our experiment was performed at temperatures ranging from 27.2 to $28.2^{\circ} \mathrm{C}$ at a depth of $50 \mathrm{~cm}$. Thus, neither solar UV radiation nor temperatures in this range caused the decline in virus infectivity.

Biological factors such as protease, anti-viral substance and other microbes are thought to be virusinactivating factors. Marine bacteria are known to produce extracellular protease (Odagami et al. 1994). Proteolytic enzymes degrade organic matter in ocean ecosystems (Davey et al. 2001), which is important in the cycling of organic matter, and these enzymes are also thought to decay viruses in the ocean. Yoshimizu et al. (1986a) reported that culture filtrate of Pseudomonas isolates from a salmonid hatchery reduced the infectivity titer of infectious hematopoietic necrosis virus (IHNV) to a non-detectable level within a $3 \mathrm{~d}$ incubation, and the virus-inhibiting factor produced by Pseudomonas was inactivated by autoclaving. Our results may be caused by a similar factor.

Environmental microorganisms play an important role in the inactivation of viruses in seawater. Kamei et al. (1987) reported a similar phenomenon, in which the infectivity of IPNV was reduced by more than 2 orders of magnitude after $7 \mathrm{~d}$ in natural seawater collected in summer, whereas the virus was stable even at $14 \mathrm{~d}$ in seawater that was autoclaved or filtered. This loss of infectivity has also been documented in other articles. Fujioka et al. (1980) reported that poliovirus was not detected in natural seawater after a $1 \mathrm{~d}$ incubation at $24^{\circ} \mathrm{C}$, but was stable even after $3 \mathrm{~d}$ in autoclaved or filtered seawater. Although MABV is relatively stable compared to other viruses against UV and high temperature, our results showed that reduction of the infectivity of MABV occurred within $3 \mathrm{~h}$ in natural seawater. A high level of anti-viral bacteria and/or degrading enzymes might have contributed to this reduction.

We have reported that MABV can be detected in both coastal areas and the open ocean (Kitamura \& Suzuki 2000, Suzuki et al. 2001), suggesting that even if infectivity was lost, genomic RNA covered by a capsid protein is stable in seawater. This study could explain why MABV can be detected by PCR but not by the cell-culture method (Kitamura \& Suzuki 2000, Suzuki et al. 2001). This present study suggests that MABV can infect host organisms for $<220$ min before the infectivity is lost. Since fish and shellfish are generally cultured at high densities in net cages, $220 \mathrm{~min}$ is enough time for MABV to infect other individuals. MABV might be able to transfer horizontally to different species, or many individuals of the same species before inactivation. Finally, we conclude that UV irradiation does not necessarily inactivate MABV in natural seawater.

Acknowledgements. We thank Drs. M. Kumagai and K. Hayakawa, Lake Biwa Research Institute, for providing PUV-500. We thank Dr. J. Bower, Hokkaido University, for his critical review of this manuscript. This work was partly supported by a Grant-in-Aid for Scientific Research A (Project No. 12308027), MEXT, a Grant-in-Aid from the Japan Society for the Promotion of Science (JSPS), and a Sasakawa Scientific Research (Project No. 14-371M) Grant from The Japan Science Society.

\section{LITERATURE CITED}

Chung H, Sobsey MD (1993) Comparative survival of indicator viruses and enteric viruses in seawater and sediment. Water Sci Technol 27:425-428

Cutrin JM, Olveira JG, Barja JL, Dopazo CP (2000) Diversity of infectious pancreatic necrosis virus strains isolated from fish, shellfish, and other reservoirs in northwestern Spain. Appl Environ Microbiol 66:839-843

Davey KE, Kieby RR, Turley CM, Weightman AJ, Fry JC (2001) Depth variation of bacterial extracellular enzyme activity and population diversity in the northeastern North Atlantic Ocean. Deep-Sea Res II 48:1003-1017

Dobos P, Hill BJ, Hallett R, Kells DTC, Becht H, Teninges D (1979) Biophysical and biochemical characterization of five animal viruses with bisegmented double-stranded RNA genomes. J Virol 32:593-605 
Fujioka RS, Loh PC, Lau LS (1980) Survival of human enteroviruses in the Hawaiian Ocean environment: evidence for virus-inactivating microorganisms. Appl Environ Microbiol 39:1105-1110

Isshiki T, Nagano T, Suzuki S (2001) Infectivity of aquabirnavirus strains to various marine fish species. Dis Aquat Org 46:109-114

Kamei Y, Yoshimizu M, Ezura Y, Kimura T (1987) Effect of estuarine and marine waters on the infectivities of infectious hematopoietic necrosis virus (IHNV) and infectious pancreatic necrosis virus (IPNV). Bull Fac Fish Hokkaido Univ 38:271-285

Kitamura SI, Suzuki S (2000) Occurrence of marine birnavirus through the year in coastal seawater in the Uwa Sea. Mar Biotechnol 2:188-194

Kitamura SI, Jung SJ, Suzuki S (2000) Seasonal changes of infective state of marine birnavirus in Japanese pearl oyster Pinctada fucata. Arch Virol 145:2003-2014

Liltved $H$, Hektoen $H$, Efraimsen $H$ (1995) Inactivation of bacterial and viral fish pathogens by ozonation or UV irradiation in water of different salinity. Aquac Eng 14: $107-122$

Maeno Y, Nakajima K (1997) Comparison of the sequential viral antigen distribution between viral deformity virus (VDV)- and yellowtail ascites virus (YAV)-infected yellowtail fingerlings following immersion infection. Fish Pathol 32:181-182

Mortensen SH, Nilsen RK, Hjeltnes B (1998) Stability of an infectious pancreatic necrosis virus (IPNV) isolate stored under different laboratory conditions. Dis Aquat Org 33:67-71

Noble RT, Fuhrman JA (1997) Virus decay and its causes in

Editorial responsibility: Jo-Ann Leong,

Kaneohe, Hawaii, USA coastal water. Appl Environ Microbiol 63:77-83

Odagami T, Morita J, Takama K, Suzuki S (1994) Substance specificities of extracelluar protease produced by marine putrefactive bacteria, Shewaanella putrfaciens and Alteromonas haloplanktis. Lett Appl Microbiol 18:50-52

Øуа AK, Rimstad E (2001) Inactivation of infectious salmon anaemia virus, viral haemorrhagic septicaemia virus and infectious pancreatic necrosis virus in water using UVC irradiation. Dis Aquat Org 48:1-5

Reed RJ, Muench H (1938) A simple method of estimating fifty percent endpoints. Am J Hyg 27:493-497

Sohn SG, Park MA, Do JW, Choi JY, Park JW (1995) Birnavirus isolated from cultured flounder in Korea. Fish Pathol 30:279-280

Sorimachi M, Hara T (1985) Characteristics and pathogenicity of virus isolated from yellowtail fingerlings showing ascites. Fish Pathol 19:231-238

Suttle CA, Chen F (1992) Mechanisms and rates of decay of marine viruses in seawater. Appl Environ Microbiol 58: 3721-3729

Suzuki S, Kitamura SI, Chiura HX (2001) Aquabirnavirus widely distributes in the ocean, providing a dissolved RNA pool. Microbes Environ 16:191-196

Yoshimizu M, Takizawa H, Kamei Y, Kimura T (1986a) Interaction between fish pathogenic viruses and microorganisms in fish rearing water: survival and inactivation of infectious pancreatic necrosis virus, infectious hematopoetic necrosis virus and Oncorhynchus masou virus in rearing water. Fish Pathol 21:223-231

Yoshimizu M, Takizawa H, Kimura T (1986b) UV susceptibility of some fish pathogenic viruses. Fish Pathol 21:47-52

Submitted: February 17, 2003; Accepted: September 12, 2003 Proofs received from author(s): February 3, 2004 